\title{
Dissents in Regulating Cultural Trade and Its Mechanisms of Dispute Settlements in Multilateral Forum: Analyzing the Roles of UNESCO and WTO
}

\author{
Annisa Pratamasari \\ Universitas Airlangga
}

\begin{abstract}
Even though the volume of trade in goods and service increases in some advanced economy countries, trade in cultural goods and services remain in neglected terrain within multilateral frameworks. WTO has indeed highlighted the importance of cultural goods' protection; however, its meaning and scopes, terms of protection, and dispute settlement on cultural goods and services have remained vague. On the other hand, UNESCO shed some lights on the trade of cultural goods and services, but some of the articles in its convention arises some contradiction with WTO clauses. The cases presented in this paper are all related to the culture trade, namely Canada for a periodical case (DS31), Turkey's taxation of foreign film (DS43), Canada's case on film distribution service (DS117), and China's case on publications and audiovisual products (DS363). This paper aims to analyze how those cases were handled in the dispute settlement of WTO and supposed to be handled by both UNESCO and WTO. I would like to draw some lessons from the inadequate dispute settlement in WTO on culture trade, then proceed to formulate some suggestions of how cultural trade-related disputes are supposed to be formulated.
\end{abstract}

Keywords: culture trade, WTO, UNESCO, dispute settlement

Meski volume perdagangan barang dan jasa telah meningkat pesat di sebagian negara maju, perdagangan dalam hal barang dan jasa terkait budaya masih tetaplah menjadi area yang terpinggirkan dalam kerangka perjanjian multilateral. Memang WTO telah menyoroti betapa pentingnya perlindungan terhadap barang-barang warisan budaya; namun, makna dan ruang lingkup, syarat perlindungan, dan penyelesaian sengketa dalam hal barang dan jasa terkait budaya masih cukup samar. Di sisi lain, UNESCO telah membuka ruang dalam hal perdagangan barang danjasa terkait budaya ini, namun sebagian artikel dalam Konvensi UNESCO menimbulkan beberapa kontradiksi dengan klausa-klausa dalam aturan WTO. Kasus-kasus yang disajikan dalam tulisan ini terkait dengan perdagangan kebudayaan, seperti kasus Kanada dalam perdagangan periodikal (DS31), kasus pajak atas film dari luar negeri di Turki (DS43), kasus Kanada dalam hal distribusi film (DS117), dan kasus Tiongkok dalam publikasi material dan produk-produk audiovisual (DS363). Studi ini bermaksud untuk menganalisis bagaimana kasus-kasus di atas ditangani oleh mekanisme penyelesaian sengketa WTO dan bagaimana kasus-kasus tersebut seharusnya ditangani oleh WTO dan UNESCO. Saya ingin menarik pembelajaran dari ketidakcukupan aturan penyelesaian sengketa di WTO untuk perdagangan budaya, lalu beranjak untuk memformulasikan beberapa saran mengenai bagaimana sengketa terkait perdagangan budaya seharusnya disusun.

Kata-kata kunci: perdagangan budaya, WTO, UNESCO, penyelesaian sengketa 
Dissents in Regulating Cultural Trade and Its Mechanisms of Dispute Settlements in
Multilateral Forum: Analyzing the Roles of UNESCO and WTO

\section{Dichotomy of Cultural Goods and Services, Cultural Heritage, and Cultural Property}

Liberalization of international trade has been blooming since the World War II ended. International efforts to regulate international trade, monetary, and finance have been conducted to prevent protectionism, rent-seeking, and imprudent behaviors which endangered international order and possibly caused crises as huge as Great Depression was. World Trade Organization (WTO) was established to correct the weaknesses of General Agreement on Tariff and Trade (GATT) and it included the "imposed for the protection of national treasures of artistic, historic or archaeological value", which signals the protection of cultural goods and cultural heritage (WTO 2018). However, it is just briefly mentioned under the Article XX of GATT 'General Exception' and is not elaborated further. Perhaps because it is commonly regarded that the protection of culture largely falls under the 'jurisdiction' of United Nation Educational, Scientific, and Cultural Organization (UNESCO). With the thickening of globalization, trade in cultural goods and services keeps increasing, along with other kinds of goods and services, and demands attention from all members of WTO and UNESCO. Cultural goods and services signify one's identity and values embedded to one's communities; it is considered highly valuable and deserves some protections against unfair trade. Therefore, the debate on regulating cultural goods and services in international trade (including dispute settlement) has been doing on for at least a decade (Singh 2015; Yu 2011).

Defining culture ${ }^{1}$ is already complicated; hence, determining what represents cultural goods, cultural property, and cultural heritage in terms of cultural trade require more concerted multilateral efforts, particularly from WTO and UNESCO. However, both organizations have different underlying meanings in defining cultural-related dictions. As conveyed by Voon (2017), even 'national treasures/heritage', 'cultural property', and 'cultural goods' stipulated under WTO and UNESCO might have different meanings. Under UNESCO Convention 1970, cultural property encompasses properties excavated by archaeologists, antiquities aged more than 100 years old, and artistic properties made by hand (Convention on Stolen or Illegally Exported Cultural Objects 1995 and Convention on the Protection of Underwater Cultural Heritage 2001 in Voon 2017).

WTO regulation does not include other cultural properties or goods which might be tradeable, despite encouraging the protection of 'national treasures' whose definition is similar to 'cultural heritage'. However, under TRIPS, it regulated the trade and protection for literary works, films, broadcasting programs, sound recordings or music, performances on the Article XIV of TRIPS (WTO 2018b). Those goods fall under the scope of cultural goods according to UNESCO Framework of Cultural Statistics (2018) which defined cultural goods as conveying ideas and ways of life and included books, magazines, multimedia products, software, recordings, films, videos, audio-visual

1 Kroeber and Kluckhohn (in Spencer-Oatley 2012), two American anthropologists, at least found 164 list of different definition of culture. Most definitions agreed that culture is deeply related to some sets of beliefs, values, norms, expressions, and way of lives. Culture is also distinguished between high culture and popular culture or mass culture, calling 'mass culture' as the left-over of high culture (Parker 2011). Ray Browne (in Delaney 2007) defined popular culture as 'consisting of aspects of attitude, behaviors, beliefs, customs, and tastes that define the people of any society. It is the culture of the people.' Culture is mostly intangible, but the expression of culture can be materialized into tangible goods or stay intangible for services in terms of culture trade. For instance, popular culture-related goods include fashion styles, slang language, television programs, pop music, food, movies, etc.; while high culture is usually associated with classical music, arts, etc. The scope of cultural goods encompasses both high culture and pop culture. 
programs, crafts and fashion within the scope. Another notable organization, European Union, defined cultural goods as 'archaeological finds, ancient scrolls, the remains of historical monuments, artwork, collections and antiques which at least 250 years old at the moment of importation and exportation' (European Commission 2017). EU's definition of 'cultural goods' is more in line with the definition of 'cultural heritage' under WTO and UNESCO.

Therefore, in order to achieve clarity in the dichotomy of those terms, this paper shall use the categorization of cultural goods based on the 2009 UNESCO Framework of Cultural Statistics (UNESCO-UIS 2016). Hence, cultural properties (both goods and services $^{2}$ ) mentioned in this paper shall encompass music, video games, performance arts, films and videos, fine arts, photography, crafts, architecture services, museums, design services, publishing, cultural education, national heritage, tourism, and sports. The categorization of cultural goods and services is depicted in Figure 1 below:

Figure 1. Categorization of culture trade's goods and services

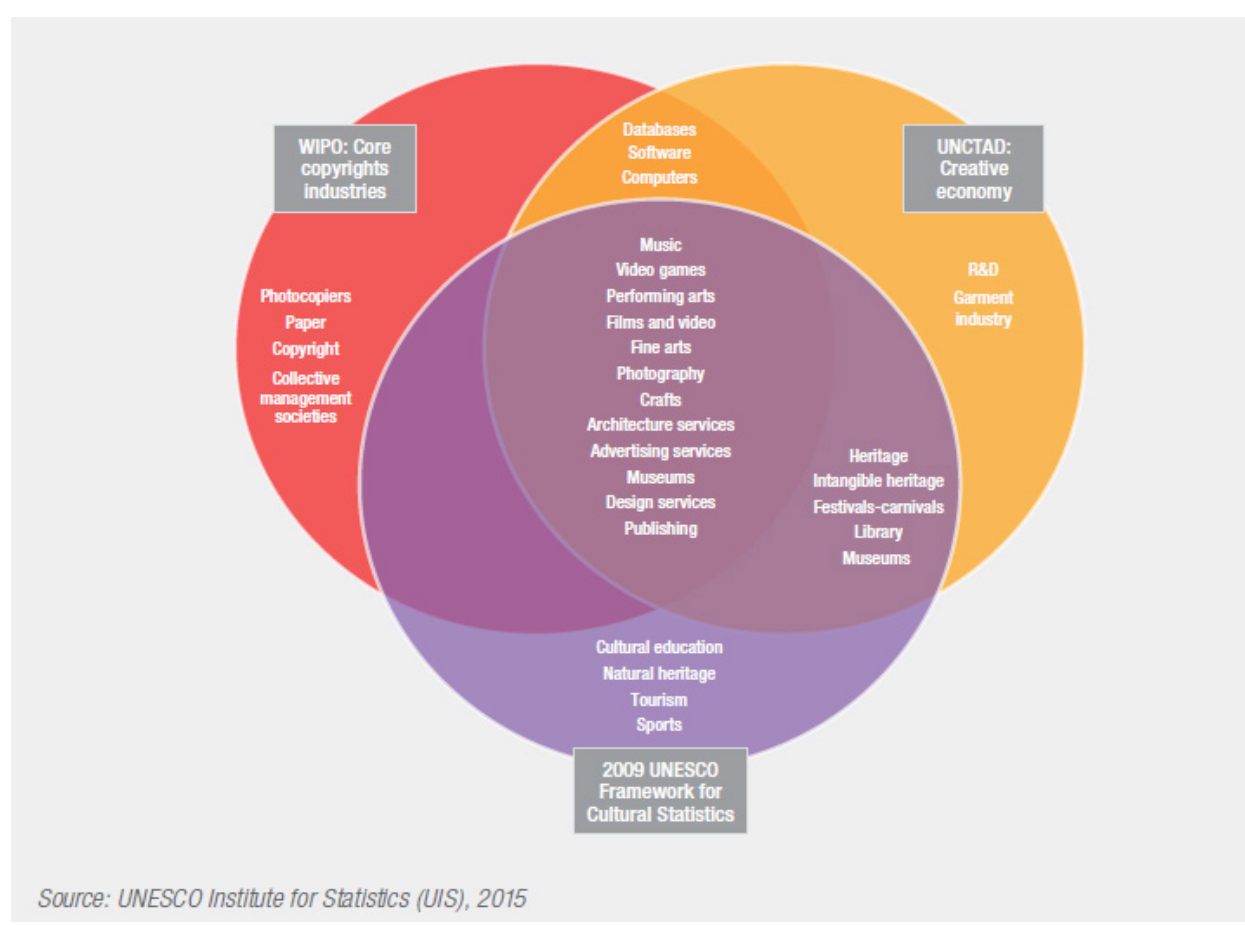

In order to measure trades in culture, UNESCO Institute for Statistics (hereafter, UNESCO-UIS) categorized components of trade in culture into 6 (six) domains. Domain A encompasses culture and natural heritage. As defined above, cultural heritage revolves around 'antiques' archaeological or historical properties of more than 100 years old. Domain B includes performance and celebration which consist of musical instruments and recorded music (like CDs or DVDs). Domain C incorporates visual arts and crafts, including jewelries, woven fabrics, and sculpture arts. Domain $\mathrm{D}$ deals with books and printed media; while electronic books or newspapers belong to trade in services. Domain E covers audiovisual and interactive media, including movies and games. Lastly, Domain F embraces the category of services (design and

22005 UNESCO Convention stated that cultural goods and services refer to any activities which contain and convey cultural expression, regardless to the commercial values they may (or may not) have (UNESCO 2005). 
Dissents in Regulating Cultural Trade and Its Mechanisms of Dispute Settlements in Multilateral Forum: Analyzing the Roles of UNESCO and WTO

service) which put architectural drawing and design graphics in it.

\section{WTO and UNESCO's Differing Views on Culture Trade and Its Protection}

Will Hays, former head of the Motion Picture Association of America (MPAA), once devised and popularized the term 'trade follows film' (Baker 2012 in Zapatero and Petz 2016), as he highlighted that US trade of goods and services reached tremendous amount of consumption internationally due to the spread and popularity of Hollywood movies and pop music. Likewise, in South Korea, due to the rise of Hallyu, cultural content export to China alone reached 6.21 billion (USD 5.52 billion) in 2016 (Korea Herald 2017). It signifies that trade in cultural goods is indeed flourished and capable of spilling over to other sectors of trades.

Increasing importance on trade in cultural goods is evidenced in the statistic data released by the UNESCO Institute for Statistics in 2016 (Figure 2 and Figure 3 below).

Figure 2. Annual growth rate of exports of cultural goods and all goods, 20042013

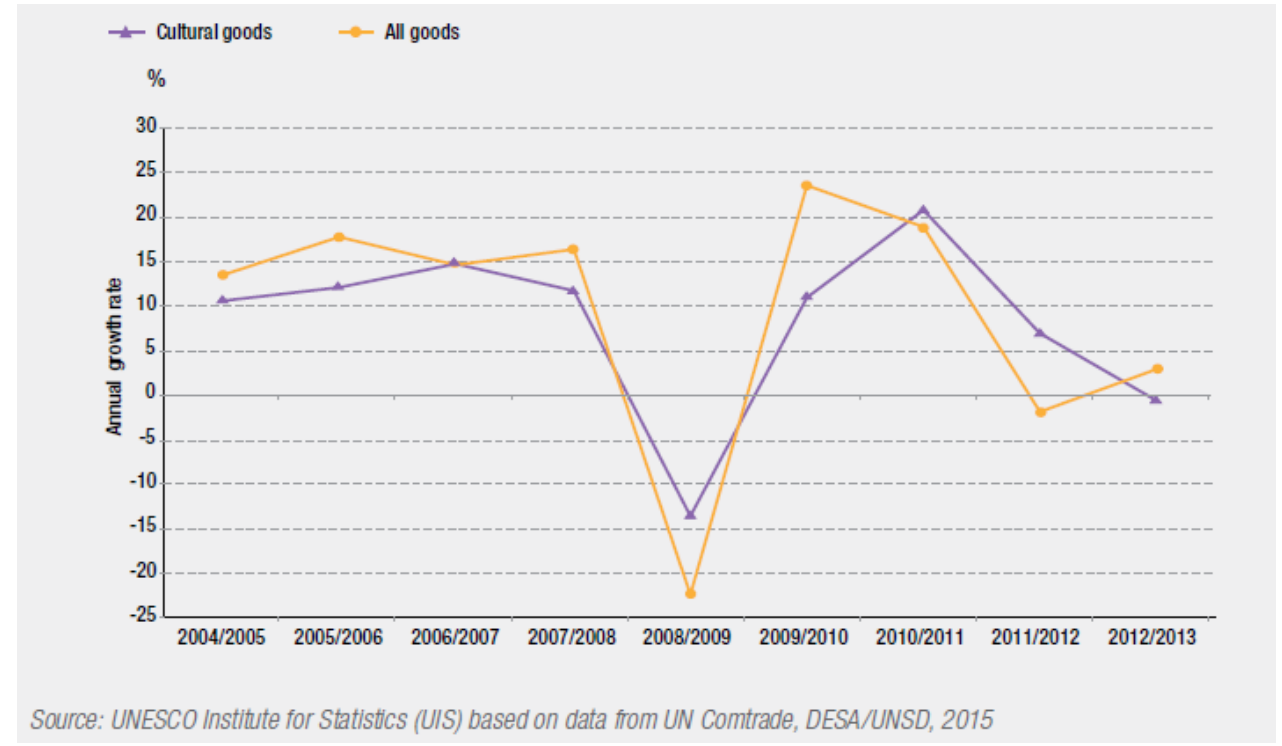

Even though in 2004 and 2006 the number of export growth of cultural goods was still below all other goods, it grew at the same amount with them in 2007. Figure 2 also shows that the export growth of cultural growth did not fall as much as other goods during Financial Crash in 2008/2009 (though it also did not rebound as bound as high as other goods after the crisis). It even rose above all other goods in 2010/2011 and 2011/2012. Meanwhile, the import growth rate in Figure 3 below displays that the import in cultural growth is still generally below all other goods; however, it surged above them in 2006/2007 with $25 \%$ growth. Similar to export growth, it also suffered a massive downturn (-20\% in growth) in 2008/2009, but it managed to rebound to more than 10\% growth in the next period. UNESCO (in Magdeleine and Maurer 2016) reported in 2013 that trade in cultural goods alone reached USD 190.5 billion in value alone. 
Figure 3. Annual growth rate of imports of cultural goods and all goods, 20042013

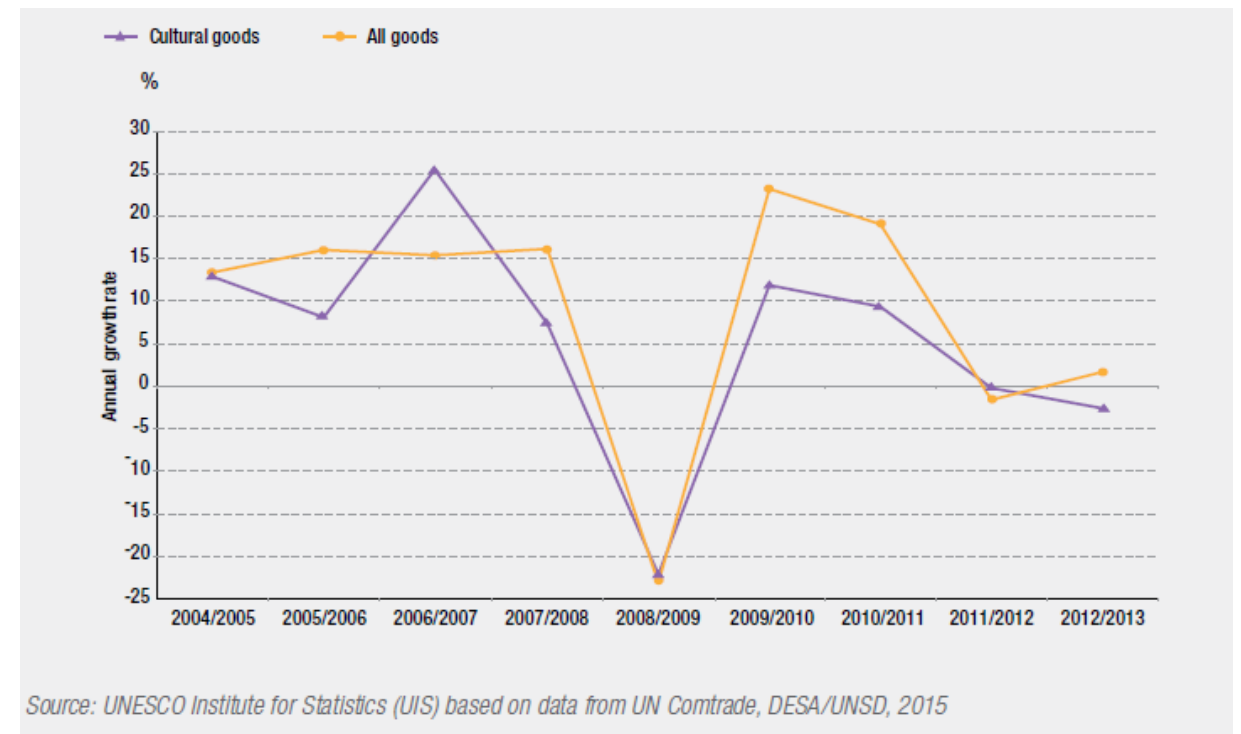

Recognizing the importance of cultural goods-related trade, in 2005, UNESCO tried to formulate a new convention on culture with protection on cultural diversity as its main theme. It encompasses more cultural-related goods and services, from the 'antiques' to 'popular culture' like books, food and beverage, tourism, and audiovisual products (UNESCO 2005). The convention was conducted amidst growing concern about the imbalance of cultural transfers (Zapatero and Petz 2016) in which developed countries, like the US and West Europeans, dominated the cultural trade and adversely affected local culture in developing countries. For instance, Sony (Japan), BMG (Germany), Universal (France), EMI (United Kingdom), and Time Warner (USA) controlled at least $80 \%$ of music sales (Germann 2004). Moreover, United States was the second largest cultural goods' exporter in the world in 2013 with recorded media (music) topping the export rate (UNESCO-UIS 2016). Therefore, UNESCO 2005 Convention was initially established to address such imbalance and exclusion of cultural goods provisions in WTO articles. J. P Singh (2015) outlined the political background of the establishment of this conference. First, trade in cultural products has been made exceptions in regulation of international trade, particularly among market-based economy. Second, those countries realize the growing importance of cultural economy issues and appeal their case to the UNESCO. Third, UNESCO's idealistic view on culture and its protection serve as valid means of justification for these countries to protect their own national interest.

Prior to the convention, the inclusion of audiovisual sector started in Uruguay Round of GATT and raised some concerns among the members due to the lack of clarity and representative for cultural-related trade (Germann 2004; Zapatero \& Petz 2016). Some countries had to give up their domestic cultural policy which aimed to protect their cultural diversity in this area, as well. The ongoing debate on the exclusion of the protection of members' cultural issues continued in 1998 under Multilateral 
Agreement on Investment among OECD members (Singh 2015), particularly under the basic principles of WTO (MFN and national treatment). Western European countries and Canada were particularly adamant on protecting their cultural industries and introducing "cultural exception" in WTO clauses, particularly movies and television programs (Singh, 2015). With regards to putting quota on movies, Article III-10 of GATT stated that WTO did not prevent the members from 'establishing or maintaining internal quantitative regulations,' or in other words permit the members to restrict the quota for the screening of foreign films and favoring national movies (Germann 2004; $\mathrm{Yu}$ 2011). Article IV also implicitly permitted quota allowance for foreign films, but it listed the provisional clauses to apply several restrictions (e.g. 'over a specific period) and further liberalization or limitation should undergo another round of negotiations between members (WTO 1996). South Korea, for instance, is under pressure of the United States to relax its restrictions on foreign movies' screening which is a part of its cultural protection.

On the other hand, for audiovisual treatment, even though there is a proposal to either eliminate exemptions under MFN or to establish a special regime for this sector only, there is a dilemma in actual implementation of it (Germann 2004). Brazil, for instance, supports the eliminate exemptions on this sector on the grounds of cultural protection; however, it realizes that developing countries generally have little fund to subsidizes products or provide financial grants in this sector. Moreover, eliminating measures which are not in line with MFN at the same time will greatly reduce the opportunity to co-produce movies. Developing countries admittedly needs such practices to continue for the sake of transfer of knowledge and technology. Nevertheless, the necessities of cultural protection outweigh the dilemma, seeing that 2005 UNESCO Convention had 146 signatories (including European Union) and being ratified by 140 parties (UNESCO 2018). The urgency of cultural protection also escalates as there have been several culture-related disputes brought before WTO's Dispute Settlement Body (DSB) and received less than satisfactory rules from the WTO panels.

\section{Disputes on Cultural Goods under WTO}

By far, there have only been few disputes for cultural-related goods and service are brought to WTO's Dispute Settlement Body (DSB). Few years after WTO'S establishment, a dispute was fought between the United States and Canada for a periodical case (DS31) and started with a consultation period on January $20^{\text {th }}, 1996$. The U.S protested Canada's import tax measures for split-run periodicals through measured by Canada Post Corporation and the Department of Canadian Heritage, which violated GATT Article III and XI (WTO 2010c). Canada claimed that government funding and support for the periodicals aimed to promote Canadian culture; however, the panel ruled that cultural protection was not an issue in this case (WTO 1997). Yu (2011) proclaimed that WTO Appellate Body admitted the dual nature of the periodicals as goods and services (editorial and advertising contents) and ruled out that GATS and GATT did not necessarily overrule or contradict each other. Critics considered the rule as a main example of WTO's negligence over its members' cultural protection (Loisen and Pauwels 2015) and Canadian government later became the primary supporter of UNESCO 2005 Convention ${ }^{3}$ partly due to this case.

3 United States later joined UNESCO as members when the negotiation and drafting process for 2005 Convention and known to challenge the cultural protection clauses in the convention, particularly 
The second case was brought by the United States against Turkey's taxation of foreign film revenues, in which Turkey charged higher tax for showing foreign movies (WTO 2010a). In this case (coded as DS43), the United States invoked Article III of GATT regarding national treatment in terms of taxation. The case was settled and terminated after both parties found a mutually agreed solution in which Turkey agreed to impose equal tax on both domestics and imported films (WTO 1997). Again, this case displays that WTO's principle of national treatment neglected developing countries' needs to protect its own cultural industries. Third, Canada's case on film distribution service (DS117), which was brought before DSB by European Committee (EC) who requested for consultation in January $20^{\text {th }}, 1998$ (WTO 1998a). EC argued that Canada violated Article II (MFN) and III of GATS (Transparency) regarding Canadian government's rules which affects film distribution service. Request for consultation was made in 1998 but halted due to the company's takeover by a European company (Germann 2004), which made them 'domestic company' so the cultural protection rules could not be applied to them.

The latest case involved China and the United States (as a complainant) about Chinese (as a respondent) publications and audiovisual products, starting in April $10^{\text {th }}, 2018$ (WTO 2012). This case is considered important, as it was the first cultural trade case which was brought before WTO DSU after UNESCO 2005 Convention was adopted (Yu 2011). For this case, he U.S invoked GATS (Article XVI - market access and XVII - national treatment), GATT (Article III: $4^{4}$ and XI:15), and Protocol of Accession (Part I, paragraph 1.2; paragraph 5.1; and paragraph 5.2). Based on the case summary, the U.S concerned about China's restrictive measures (distribution rights, duties, content review regime) through its state-owned enterprises (wholly or partially) on theatrical releases, audiovisual products (DVDs and VCDs), sound recordings, and publications (including electronic publications, books, periodicals, newspapers, and magazines). In this case, China asserted its rights to regulate its own cultural products and reaffirmed that the cultural protection is tightly related to public morale (WTO 2009). Similar to Canada's periodical case (DS31), China argued that it only imposed tax for the content of the films, not the films as the products or who imported the films per se (Yu 2011). In the end, WTO panel ruled against China and did not clear out the confusion between contents and good.

Cases with China (DS363) and Canada (DS31) signals the fuzziness in distinguishing between cultural goods and services; while other two cases can clearly invoke GATT (tax for Turkey case) and GATS (distribution service), respectively. This kind of fuzziness is perhaps caused by differing notion of the meaning of culture and cultural-related goods itself. Is culture something that is actually tradeable and commercialized? Or should it stay as the values and norms which live within society, as it has been anthropologically defined? Should culture be regarded as 'special kinds' of goods and services and be protected? Or should it be treated the same as other commercialized tradeable goods and services?

Categorizing culture into goods (tangible cultural contents: cinema, CD/DVDs,

those disadvantaged their entertainment industry (Loisen and Pauwels 2015; Singh 2015)

$4 \quad$ National treatment provisions which prohibited differentiation between domestics and foreign companies, including in terms of internal sale, offering for sale, purchase, transportation, distribution or use.

5 On quantitative measurement where it is stated that any parties are prohibited to impose quotas, import or export license, or other measures. 
television programs, etc.) or services (intangible cultural contents: editing, forms of expression and diversity, distribution service, etc.) are bound to meet with some challenges (Zapatero and Petz 2016; Yu 2011). Furthermore, the inclusion of cultural goods and services as tradeable goods and services also brings about some debates about to what extent 'cultural exception' should be granted, to whom, and even what exactly does it mean. Loisen and Pauwels (2015) argued that the economic value of cultural goods should be well-regarded and well-regulated, especially in the globalization era where production and distribution of cultural goods will be subjected to fast economic development. With regards to this issue, 2005 UNESCO Convention addressed it in Article 2-5, linking both economic and cultural aspects in which "individuals and peoples have the fundamental right to participate in and enjoy" (UNESCO 2005). Since this issue shall have global implications and expand in terms of importance in the future, I argue that global/multilateral efforts are required to formulate well-design regulations to tackle it.

\title{
Cultural Goods Dispute Settlement: How it should be
}

There are two streams of debate on whether dispute settlement on culture-related trades should be negotiated under WTO DSB or UNESCO Convention or other means. One side argued that WTO does not permit WTO members to pursue dispute settlement under other international organizations (Marceau 2001) based on Article 23.1 on WTO's Dispute Settlement. The article stated that:

\begin{abstract}
"When Members seek the redress of a violation of obligations or other nullification or impairment of benefits under the covered agreements or an impediment to the attainment of any objective of the covered agreements, they shall have recourse to, and abide by, the rules and procedures of this Understanding" (WTO 2018c) (emphasis added by the author).
\end{abstract}

On the other hand, another side repudiated such claim, postulating that both organizations are not necessarily at odds against each other on this case (Voon 2006), because Article 23 only covers the provisions agreed under WTO rules. Therefore, if there is a dispute related to culture trade issues, nation-states can invoke UNESCO Convention's rules instead of WTO's. This claim is strengthened by Article 3.2 and Article 3.9 of Dispute Settlement which stated that:

\footnotetext{
"The Members recognize that it serves to preserve the rights and obligations of Members under the covered agreements, and to clarify the existing provisions of those agreements in accordance with customary rules of interpretation of public international law" ... "The provisions of this Understanding are without prejudice to the rights of Members to seek authoritative interpretation of provisions of a covered agreement..." (emphasis added by author)
}

However, it is also undeniable that some of the cultural goods which are traded internationally fall under both jurisdictions of WTO and UNESCO. This kind of concern was visibly raised by members of both WTO and UNESCO (Voon 2006; Germann 2004).

Furthermore, Article XX of GATT on protection of national heritage and cultural 
property has never been directly invoked by WTO members, besides China in its arguments in DS363 case (and resulted in an unfavorable lost). Voon (2017) posited that it might be caused by several factors. Firstly, it is unclear to what extent WTO law is willing to refer to UNESCO Convention to interpret Article XX of GATT, despite differences in the interpretation. It has only referred to non-WTO law as 'factual reference' and proved to be reluctant to do so on the ground of maintaining consistency of WTO law. Secondly, it is undecided whether WTO would take such case into account if a WTO member invokes Article XX against a non-member (but the other party might be UNESCO member), or whether WTO would consider if the article is invoked not to protect the complainant's own culture, but to protect the importing country's culture, as reflected from EU's case for the importation of Syria's cultural properties in order to save it from being destructed by ISIS (EUR-Lex 2015). Lastly, by far, only two disputes have succeeded in invoking Article XX of GATT in WTO; one of them was US-Shrimp case (WTO 1998b) in which USA won on the ground of sea turtle protection. Even for this case, the WTO applied stringent measures which might not be successful to justify import or export restriction on cultural properties against the basic principle of nondiscrimination (Most Favored Nations and National Treatment) (Germann 2004). Furthermore, even though the WTO members may introduce some cultural protection measures, it may not do so as a precaution or prevention step, because international law does not permit such step to be taken.

Meanwhile, UNESCO also implicitly addresses the possible clashes with other international treaties under its 2005 Convention's Article 20, which is titled as 'Relationship to other treaties: mutual supportiveness, complementarity and nonsubordination.' The article ambiguously stated that it encourages all parties to commit to the Convention and other treaties they are under without undermining one another ("foster mutual supportiveness between this Convention and the other treaties" and "when interpreting and applying the other treaties...parties shall take into account the relevant provisions of this Convention") and that the Convention's clauses are in no way modify the UNESCO members' rights and obligations under other treaties (UNESCO 2005). Zapatero and Petz (2016) argued that these vague clauses were caused by disagreements among Convention's parties as well. On one hand, led by European ministers, some countries support special treatment for cultural goods and service. On the other hand, the United States, Australia, and Japan publicly stated that the Convention was a cover for protectionism measures. Singh (2015) further highlighted that such clause weakened the convention's position as an international law, because based on Vienna Convention on the Law of Treaties, the convention is supposed to supersede the older international law, which was under WTO rules.

Loisen and Pauwels (2015) analyzed how UNESCO Convention had worked for its $10^{\text {th }}$ anniversary and concluded that UNESCO's efforts to address the economic sides of cultural globalization have largely failed, as the convention is not as legally-binding as the WTO regulations. On the other hand, WTO remains negligence on the cultural related issues. It can also be said that lack of synergies between both organizations have caused the regulation of culture trade and the formulation of its dispute mechanism in a stalemate. Zapatero and Petz (2016) offered that WTO had two alternatives to address this issue under WTO institutions and law, namely integration and confrontation. To achieve this, certain compromises and concessions between WTO law and UNESCO conventions shall be synergized, instead of adamantly remaining mutually exclusive like they currently are. Such efforts will also require additional measures to ensure 
compliance mechanism from their members, as well as aligning the categorization of cultural goods and services clearly. Furthermore, related to dispute settlement, both organizations need to sort the sources of previous cultural trade dispute, how the dispute was investigated and treated, and how the resolution was drawn, in order to find common solutions on tackling this issue.

Moreover, as mentioned in the first section of this paper, WTO addressed the protection of rights to 'cultural goods' under Article XIV of TRIPS. Hence, TRIPS might be the 'middle-way' between UNESCO and WTO in this issue, because most cultural contents are related to the concept of 'expressions' and 'ideas.' Moreover, most cultural and creative contents are increasingly digitalized under the protection of trademark and copyright, and the trade in digitalized culture alone reached USD 670 billion in 2014 (Magdeleine and Maurer 2016).

\section{Conclusion}

The linkage between culture and trade and how to fit cultural goods and services in international trade remain debatable. Even with the existence of UNESCO 2005 Convention and WTO's/UNESCO's members about this issue, the debate has not ceased yet, let alone finding a solution. As examined by this paper, there are at least two inherent problems on this issue. Firstly, there is lack of general agreement on the division between goods and services in culture, which leads to confusion in the interpretation of WTO's law (as the more legally-binding law compared to UNESCO Convention). Secondly, there is a lack of synergy between both international organizations to sit together and formulate linear regulations for this matter.

As the globalization in culture intensified, along with more and more digitalized contents' production and consumption, cultural trade (including issues related to intellectual property rights in cultural contents) in the information era will relentlessly gain more prominence. Currently, even UNESCO-UIS showed in the report that the trade in cultural goods and services in some regions have passed the trade in 'conventional goods and services.' Therefore, there is an urgency to regulate a wellformulated regulation along with mechanism of dispute settlements before more unfair trade practices unfold.

\section{References}

\section{Book and Chapter in Books}

Loisen, Jan, and Pauwels, Caroline, 2015. "Competing Perspectives? WTO and UNESCO on Cultural Diversity in Global Trade", in Christiaan De Beukelaer, Miikka Pyykkönen, and J. P. Singh (ed.), 2015. Globalization, culture and development: the UNESCO Convention on Cultural Diversity. New York: Palgrave Macmillan.

Singh. J. P, 2015. "Cultural Globalization and the Convention", in Christiaan De Beukelaer, Miikka Pyykkönen, and J. P. Singh (ed.), 2015. Globalization, culture and development: the UNESCO Convention on Cultural Diversity. New York: Palgrave Macmillan. 


\section{Journals and Online Journals}

Germann, Christophe, 2004. "Diversite culturele a l'omc et l'unesce a l'exemple du cinema”, Revue Internationale de Droit économique, XVIII (3): 325-354.

Magdeleine, Joscelyn, and Maurer, Andreas, 2016. "Understanding trade in digitized ideas: What are the statistical challenges?” WTO Working Paper, ERSD-2016-11.

Marceau, Gabrielle, 2001. "Conflicts of norms and conflicts of jurisdictions: the relationship between WT agreement and MEAs and other treaties", Journal of World Trade, 35 (6).

Parker, H. N., 2011. "Toward a definition of popular culture." History and Theory. (50): 147-170.

Yu, Li, 2011. "WTO and National Cultural Policy: Rethinking China Measures Affecting Trading Rights and Distribution Services for Certain Publications and Audiovisual Entertainment Products", [online] in https://ssl.editionsthemis.com/uploaded/ revue/article/31849_45-3\%20Yu.pdf

Zapatero, Miguel P. and Petz, M., 2016. "Building synergies between WTO and UNESCO: the case for data-driven policy coordination", International Journal of Cultural Policy, [online] in http://dx.doi.org/10.1080/10286632.2016.1184660 [accessed 15 November 2018]

Voon, Tania, 2006. "UNESCO and WTO: a clash of culture?" The International and Comparative Law Quarterly, 55 (3, July): 635-651.

Voon, Tania, 2017. "Restricting trade in cultural property: national treasures at the intersection between cultural heritage and international trade law." [online] in https://ssrn.com/abstract=3093448 [accessed 15 November 2018]

\section{Online Articles}

Delaney, Tim. 2007. "Pop culture: an overview. Philosophy Now", [online]. in https:// philoshophynow.org/issues/64/pop_culture_an_overview [accessed 27 November 2018].

EUR-Lex, 2015. "European Parliament resolution of 30 April 2015 on the destruction of cultural sites perpetrated by ISIS/Da'esh”, [online] in https://publications.europa. eu/en/publication-detail/-/publication/816104bf-7fc6-11e6-bo76-01aa75ed71a1/ language-en [accessed 10 December 2018].

European Commission, 2017. "Cultural Goods". [online] in https://ec.europa.eu/ taxation customs/business/customs-controls/cultural-goods en [accessed 23 November 2018].

Korea Herald, 2017. "Exports of Korean cultural content up 9.7\% in 2016", [online] in http://www.koreaherald.com/view.php?ud=20170611000044 [accessed 20 November 2018]. 
Dissents in Regulating Cultural Trade and Its Mechanisms of Dispute Settlements in Multilateral Forum: Analyzing the Roles of UNESCO and WTO

UNESCO Framework of Cultural Statistics, 2018. "Definition of Cultural Goods". [online] in http://uis.unesco.org/en/glossary-term/cultural-goods [accessed 23 November 2018].

Spencer-Oatey, H., 2012. "What is culture? A compilation of quotations." GlobalPAD Core Concepts. [online] in https://warwick.ac.uk/fac/soc/al/globalpad/.../ global pad - what is culture.pdf [accessed 23 November 2018].

UNESCO, 2018. "Parties to the Convention", [online] in http://www.unesco.org/ new/en/culture/themes/cultural-diversity/cultural-expressions/the-convention/ parties-to-the-convention/ [accessed 20 November 2018]

\section{Others}

UNESCO Institute for Statistics (UNESCO-UIS), 2016. "The globalization of cultural trade: a shift in consumption international flows of cultural goods and services 2004-2013." Canada: UNESCO-UIS.

UNESCO, 2005. "2005 Convention on the Protection and Promotion of the Diversity of Cultural Expressions.” Paris: UNESCO.

World Trade Organization (WTO), 1996. "General Agreement on Tariffs and Trade". Geneva: WTO.

World Trade Organization (WTO), 1997. "Turkey - taxation of foreign film revenues: notification of mutually agreed solution (WT/DS43/3)" [online] in https://bit. ly/2FLyUYb [accessed 30 November 2018] 